\title{
Reliability and Validity of the Turkish Version of the Brief Scales for Coping Profile in Textile Workers
}

\author{
Ozlem Koseoglu ORNEK ${ }^{1 *}$ and Guler Yavuz Temel ${ }^{2}$ \\ ${ }^{1}$ Department of Nursing, Turkey \\ ${ }^{2}$ Department of Educational Sciences, Turkey \\ *Corresponding author: Ozlem Koseoglu ORNEK, Assistant Professor, Department of Nursing, Faculty of Health Sciences, Istanbul Bilgi University, \\ Dolapdere Kampus, Hacıahmet Mahallesi, Pir Hüsamettin Sokak No: 20, 34440 Beyoğlu, İstanbul, Turkey
}

Submission: 眥 October 27, 2017; Published: 㠿 December 12, 2017

\begin{abstract}
Background: Work related stress is very important issue among workers. It causes many different health problems. Coping strategies are key factors for dealing with and controlling job stress. The Brief Stress Coping Profile (BSCP) is documented to assess coping profiles of workers.

Purpose: The aim of this study is to adapt the BSCP scale to Turkish and to investigate its psychometric properties among textile workers.

Methods: This is a psychometric study with cross-sectional design. After translation procedures, the BSCP was administered to workers from textile factories in 2015. Content validity of the BSCP was investigated with the CVI index and construct validity was investigated with exploratory and confirmatory factor analysis. Reliability of the BSCP was investigated with Cronbach's Alpha.

Result: The psychometric properties of the original BSCP were supported by the Turkish version of the BSCP. According to the exploratory factor analysis, the BSCP had six subscales. The model consisted of six factors provided a good model fit. Finally, the reliability of the BSCP was computed and these values were $0.692,0.712,0.661,0.756,0.786$, and 0.777 respectively. The reliability values of the Turkish version of the BSCP are similar or higher than the original BSCP. The Turkish version of the BSCP showed acceptable reliability and validity.

Conclusion/Implications for practice: Evidence of acceptable reliability and validity of Turkish version of the Brief Scale of Coping Profiles supports its application in assessing of coping profiles with stress among Turkish workers. It is the first adapted scale in Turkey for evaluating workers' coping strategies. The scale will be a good option to provide basic data about workers' coping profiles which may be used for prolonging stress management skills and health promotion programs by occupational health professionals.
\end{abstract}

Keywords: BSCP scale; Coping profiles; Work related stress; Reliability

\section{Introduction}

In Turkey, there are 30,855,000 employees according to recent official data. Labour force participation rate is almost $52 \%$. Among the working sector, textile and clothing is the most popular field after the automotive sector [1]. Turkey was within the first 15 textile-exporting countries in 2012 after Taiwan [2]. It is very clear that there are many risk factors such as job stress at the workplace which have a strong influence on workers' health but no national comprehensive research has been conducted yet. However, it is still possible to estimate the outcomes of job stress according to data in the United Kingdom and Japan. In 2015/2016, job stress caused $45 \%$ days of lost work and $37 \%$ work related health problems in Great Britain [3]. More than $60 \%$ of workers in Japan have anxiety and more than half of Japanese workers were found to be on leave due to mental health [4].

Coping strategies are key factors for dealing with and controlling work related stress. These can be classified as problem-focused and emotional-focused coping strategies. Each classification of the strategies has different ways of cognitive procedure, behaviors and outcomes [5]. Problem-focused coping forthrightly address stressors while emotional-focused profiles alleviate stress responses instead of assaying to resolve job stressors [6]. Socio-economic conditions, demographic characteristics, social support, culture, experience, knowledge and skills, workload, working hours, role uncertainty, job insecurity, and social power have important effects on workers' job stress and coping profiles $[7,8]$. Coping profiles of workers can be related to healthy life behaviour, perceived stress level, mental health problems and the success of controlling stress. In the study of Doron, Trouillet, Maneveau, Neveu, and Ninot, 2014; high copers and avoidant copers showed higher level of perceived stress and unhealthy behaviour while adaptive copers were found to have less stress and more healthy behaviour [9]. Workers that have dinner late in night had a significant correlation with perceived stress, and the ones who reported perceived stress had" emotional expression 
involving others" coping profile [10]. Avoidance and suppression coping profile was found to be correlated with depression, somatic symptoms, negative thoughts among persons who had irritable bowel syndrome [11], and low back pain with nurses was found to be associated with the "changing point of view" profile [6].

People spend much of their life time at work. Working conditions and environments have strong influences on job stress. In that regard, it is vital to know how workers cope with stressors. Therefore, basic data about the coping profiles of workers are needed to plan intervention programs at the work place for improving effective coping strategies. Also, this data is essential for the development of valid and reliable measurements. Generally, there are variety scales or questionnaires that measure coping strategies which are used internationally but seldom in Turkey. For example, the ways of coping questionnaire, COPE inventory, the coping flexibility scale, the perceived ability to cope with trauma [12] and Coping with Harassment Questionnaire [7] have been used abroad. The Brief COPE scale also has been used widely in research to assess coping strategies which contains 28 items and 14 two-item subscales [9,13-15]. Among coping measurements, the Coping style scale has been used in Turkey which was derived from Lazarus and Folkman's Ways of Coping Inventory. However, the main purpose of the scale was assessing students' profiles but it also has been used with a variety of members of the community except workers. It contains 30 items and 5 subscales [16-22]. Among the coping profiles' measurements, The Brief Stress Coping Profile (BSCP) scale was developed with the purpose of measuring coping profiles of workers. It has been used widely internationally in many different studies $[4,6,10,23,24]$. The BSCP consist of 18 items and corresponds to various coping profiles [25].

Due to the lack of a well-established short recent coping profile scale in Turkey, the study investigated the reliability and validity of the Turkish version of the BSCP in the textile factory workers.

\section{Method}

\section{Procedures and participants}

The population group of the study consisted of 553 textile workers from three textile factories in Istanbul, Turkey. The scale was conducted in the factories by a researcher in February 2016. Initial recruitment targeted all workers who were older than 18 years, had no diagnosed psychological or psychiatric diseases and who were literate. However, only 540 workers fully completed the questionnaire because 2 workers declined to participate, 3 of them had a diagnosed psychological health problem, 3 workers submitted incomplete questionnaires, 3 workers were illiterate and 2 workers were on sick leave on the days that the data was collected. The final sample included 294(54.4\%) males and 246(45.6\%) females. The mean age of the participants was $33.34 \pm 10.22$ years. Almost $79 \%$ of them graduated from elementary school and $19 \%$ of them graduated from high school. Over $67 \%$ of them expressed their economic condition as "good" and $25.6 \%$ of them expressed it as "bad". The average of daily working hours was $11.46 \pm 1.36$.
Ethical consideration: The Ethics Committee of Istanbul Medipol University approved the study procedure (approval no: 10840098-299).

\section{Instrument}

\section{The brief stress coping profile}

The BSCP consisted of 18 items rated on a 4-point scale (often, sometimes, seldom, or never). It is a self-rating scale for assessing workers' coping profile. It was developed by Kageyama, Kobayashi, Kawashima, \& Kanamaru (2004) [25]. It has 6 subscale which are; "Active solution (the item 1,2,3)", "Seeking help for solution (the item 4,5,6)", “Changing mood (the item 7,8,9)", “Changing a point of view(the item 10,11,12)", "Emotional expression involving others(the item 13,14,15)" and "Avoidance and suppression(the item 16,17,18)". Each of these sub scale has 3 items and has a score range of 3-12 points. If a respondent shows a high score for a subscale, this means he/she frequently chooses that kind of coping method [4].

The Cronbach's alpha coefficients in the original BSCP scale ranged from 0.64 to 0.77 ( 0.71 for Active solution, 0.69 for Seeking help for solution, 0.77 for Changing mood, 0.71 for Changing a point of view, 0.64 for Emotional expression involving others, 0.72 for Avoidance and suppression). A principal axis factor analysis yielded a six-factor structure [25].

\section{Translation Procedure}

The BSCP was first translated from English into Turkish by a bilingual language expert and an occupational health professional. Then, the scale was translated back into English by two translators (medical physician and psychologist consultant). The English, Turkish and "back-translated" versions were discussed by an expert panel on occupational health. The preliminary version of the Turkish BSCP scale was formed after this discussion and comparison of the versions (Appendix1-2). In a pilot study, the textile workers (N: 25) found this version to be understandable, meaningful and relevant.

\section{Statistical Analyses}

This study aimed to investigate the psychometric properties of the BSCP. First of all, translation of the scale was completed. Then, validity and reliability of the scale was investigated. Content validity index was used for evaluation of the BSCP's validity. Construct validity of the BSCP was investigated with exploratory and confirmatory factor analysis. Reliability of the BSCP was computed with Cronbach's Alpha which determines the internal consistency of the items.

\section{Content Validity Procedures}

Content validity was conducted to assess the clarity, correlation and comprehensiveness of the developed Turkish version of the BSCP. The content validity index (CVI) used was developed by Waltz \& Bausell in 1983 [26]. The content validity was assessed by an expert panel of 6 academics, with three from the field of public 
health nursing, one from psychiatric nursing, one from public health (physician) and one from the psychology field. The panelists rated the relevance and feasibility of each item on a scale from 1 (least relevant) to 4 (highly relevant). The CVI scale was calculated by dividing the number of each item rated either3 (relevant but needing minor revision) or 4 (very relevant) by the total numbers of items. It is indicated by many researchers that a CVI scale of 0.80 score or higher is acceptable for confirming expert validity [27].

\section{Result}

The results of validity and reliability of the BSCP is given below.

\section{Content validity}

Content validity was analysed with the CVI index. In the present study, the CVI was computed to be 0.88 .Construct validity of BSCP was investigated with exploratory and confirmatory factor analysis and reliability of the scale was computed with Cronbach's Alpha. Factor structure of the BSCP was determined with exploratory factor analysis. The scale was administered to 540 people. Exploratory factor analysis was examined with 180 of them and Confirmatory factor analysis was examined with 360 of them.

\section{Construct validity}

Exploratory factor analysis: First of all, Kaiser-Meyer-Olkin (KMO) value and Bartlett's Test was investigated. According to the results, the KMO index was 0.703 and the Bartlett Test's value was smaller than 0.05 ( $\mathrm{p}=0.000)$. For accepting the sample adequacy, KMO and the Bartelett's test played an important role. Because the index of KMO was over 0.06 and the Bartlett's Test of Sphericity was less than 0.05 , the sampling adequacy was accepted as suitable for factor analysis [28]. The number of significant factors was investigated with the table of the Total Variance Explained. The six factors have eigenvalues greater than 1.0 (which is a common criterion for a factor to be useful).

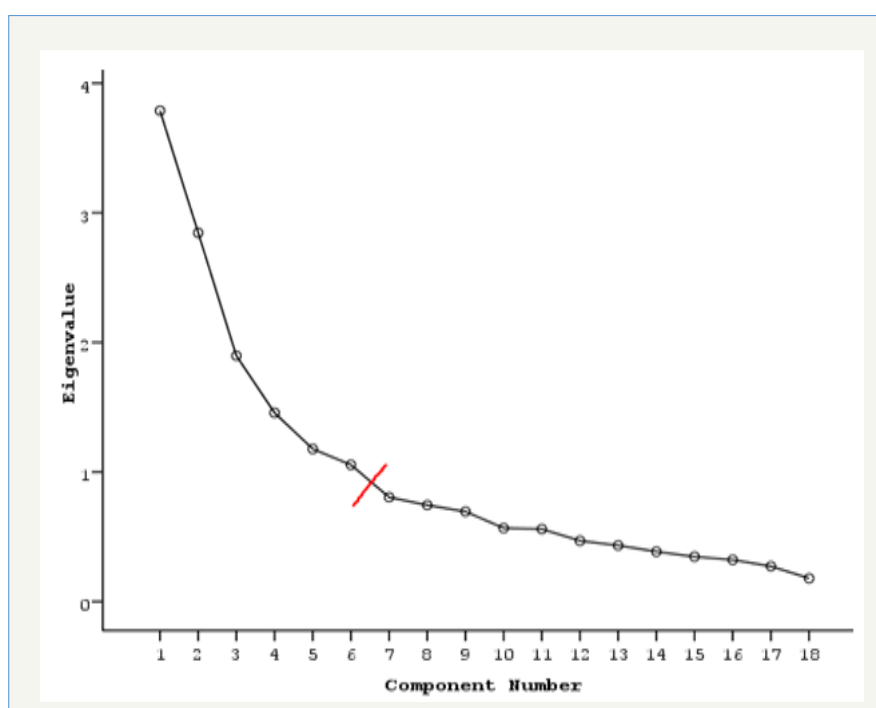

Figure 1: Scree Plot of the Turkish Version BSCP.

For determining the number of the factors, one of the important criteria is the screen plot [29] which shows the eigenvalues on the $\mathrm{y}$-axis and the number of factors on the $\mathrm{x}$-axis. It always displays a downward curve. The point where the slope of the curve is clearly leveling off (the "elbow) indicates the number of factors that should be generated by the analysis. According to the scree plot the last big drop occurred between sixth and seventh components, so six components were chosen (Figure 1).

The table of component matrix shows the factor loadings for each variable and the loadings (extracted values of each item under 6 variables) of the eighteen variables on the six factors extracted (Table 1).

Table 1: Total variance explained of the Turkish version BSCP.

\begin{tabular}{|c|c|c|c|c|c|c|}
\hline \multirow[t]{2}{*}{ Component } & \multicolumn{3}{|c|}{ Initial Eigenvalues } & \multicolumn{3}{|c|}{ Extraction Sums of Squared Loadings } \\
\hline & Total & $\%$ of Variance & Cumulative \% & Total & $\%$ of Variance & Cumulative \% \\
\hline 1 & 3,788 & 21,045 & 21,045 & 3,788 & 21,045 & 21,045 \\
\hline 2 & 2,845 & 15,807 & 36,852 & 2,845 & 15,807 & 36,852 \\
\hline 3 & 1,897 & 10,540 & 47,392 & 1,897 & 10,540 & 47,392 \\
\hline 4 & 1,456 & 8,091 & 55,483 & 1,456 & 8,091 & 55,483 \\
\hline 5 & 1,178 & 6,544 & 62,027 & 1,178 & 6,544 & 62,027 \\
\hline 6 & 1,055 & 5,862 & 67,889 & 1,055 & 5,862 & 67,889 \\
\hline 7 & ,805 & 4,474 & 72,363 & & & \\
\hline 8 & ,745 & 4,137 & 76,501 & & & \\
\hline$\ldots \ldots \ldots \ldots$ & ........... & ............. & $\ldots \ldots \ldots \ldots$ & & & \\
\hline 18 & 180 & 999 & 100,000 & & & \\
\hline
\end{tabular}

Confirmatory factor analysis: According to the results of the exploratory factor analysis, the BSCP had six factors and the results were similar with the original scale. In addition to this, the factor structure of the scale was also investigated with confirmatory factor analysis (CFA). The model which consisted of six factors provided a good model fit. The CFA fit indices of the model are given in Table 2 and the path diagram of the model is given in the Figure 2 . 
Table 2: Table of component matrix of the Turkish version BSCP.

\begin{tabular}{|c|c|c|c|c|c|c|}
\hline & \multicolumn{6}{|c|}{ Component } \\
\hline & 1 & 2 & 3 & 4 & 5 & 6 \\
\hline item 14 & ,853 & & & & & \\
\hline item 13 & 822 & & & & & \\
\hline item 15 & ,740 & & & & & \\
\hline item 11 & & ,856 & & & & \\
\hline item 12 & & ,787 & & & & \\
\hline item 10 & & 683 & & & & \\
\hline item 17 & & & ,868 & & & \\
\hline item 16 & & & ,798 & & & \\
\hline item 18 & & & ,787 & & & \\
\hline item 4 & & & & 816 & & \\
\hline item 5 & & & & ,769 & & \\
\hline item 6 & & & & ,543 & & \\
\hline item 2 & & & & & 830 & \\
\hline item 1 & & & & & ,750 & \\
\hline item 3 & & & & & 643 & \\
\hline item 9 & & & & & & ,792 \\
\hline item 8 & & & & & & ,717 \\
\hline item 7 & & & & & & ,671 \\
\hline
\end{tabular}

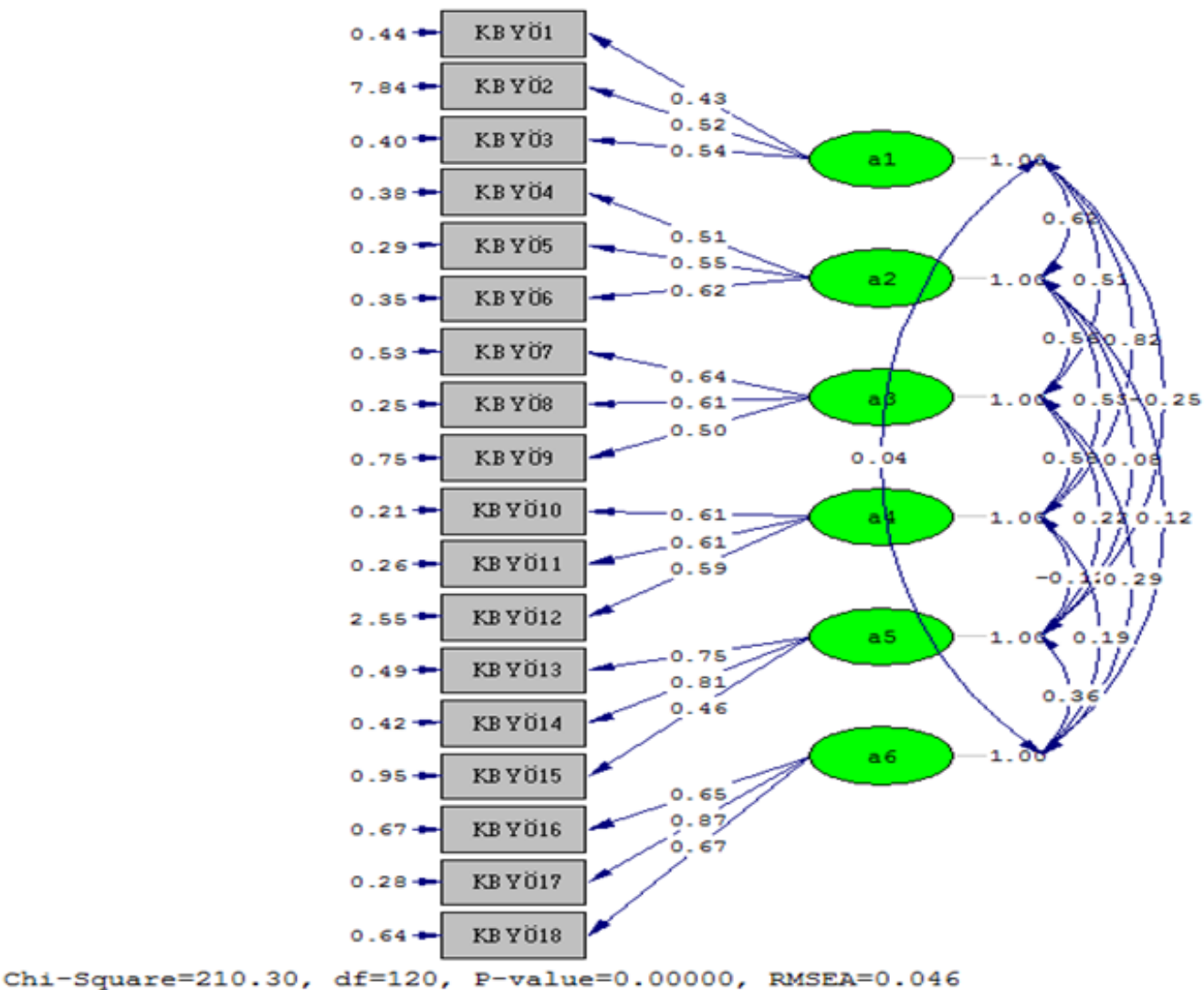

Figure 2: Conceptualization of IDC in the context of mental healthcare. 
First of all, fit indices were examined to evaluate the overall fit The chi-square goodness-of-fit statistic was statistically significant but the chi-square statistic is sensitive to the sample size, so it is rarely used as a sole index of the model fit. An adjunct discrepancybased fit index is the ratio of chi-square to degrees of freedom $(\chi 2 / d f)$. If that ratio is in the range of 2 to 3 , it is indicative of an acceptable fit between the hypothesized model and the sample data [30]. According to Table 2, this value was computed as 1.753 and the model demonstrated an acceptable fit. In addition to these, several indices of fit (CFI (0.96), NFI (0.92), NNFI (0.95), IFI (0.96), GFI (0.94)) were examined. All these incremental indices are scaled from 0 (no fit) to 1 (perfect fit). Researchers [30,31] advise that values close to 0.95 are indicative of a good fit. According to the results of the study, all indices were close to 0.95 . Finally, the root mean square error of approximation (RMSEA) is a population discrepancy function that compensates for the effects of the model's complexity. The closer the RMSEA coefficient is to 0 , the better the fit of the model. The RMSEA value of .05 or less indicates a close fit of the model in relation to the degrees of freedom, whereas a value of .08 or less indicates a reasonable error of approximation. In this study RMSEA was computed as 0.046 . According to all these results, the model which had six factors, demonstrated a good fit (Table 3).

Table 3: Confirmatory factor analysis, FIT indices results of the Turkish version BSCP.

\begin{tabular}{|c|c|c|c|c|c|c|c|c|}
\hline $\mathbf{n}$ & $\begin{array}{c}\text { Chi-square } \\
\text { (df) }\end{array}$ & $\chi^{2} / d f$ & CFI & NFI & NNFI & IFI & GFI & RMSEA \\
\hline 360 & $210.3(120)$ & 1.753 & 0.96 & 0.92 & 0.95 & 0.96 & 0.94 & 0.046 \\
\hline
\end{tabular}

Reliability (Internal consistency): The reliability of the BSCP' factors was determined with the Cronbach Alpha coefficient. Such as, the reliability of the "Active solution" factor was computed as 0.692 , the reliability for the "Seeking help for solution (the item $4,5,6$ )" factor was 0.712 , for the "Changing mood" was 0.661 , for the "Changing a point of view" was 0.756, for the "Emotional expression involving others" was 0.786 and "Avoidance and suppression" was 0.777 .

Table 4: The Cronbach alpha coefficients of the Turkish version BSCP.

\begin{tabular}{|c|c|c|c|c|c|c|}
\hline Factors & Active Solution & $\begin{array}{c}\text { Seeking Help for } \\
\text { Solution }\end{array}$ & Changing Mood & $\begin{array}{c}\text { Changing a Point } \\
\text { of View }\end{array}$ & $\begin{array}{c}\text { Emotional } \\
\text { Expression } \\
\text { Involving Others }\end{array}$ & $\begin{array}{c}\text { Avoidance and } \\
\text { Suppression }\end{array}$ \\
\hline Items & $(1,2,3)$ & $(4,5,6)$ & $(7,8,9)$ & $(10,11,12)$ & $(13,14,15)$ & $(16,17,18)$ \\
\hline $\mathrm{r}$ & 0.692 & 0.712 & 0.661 & 0.756 & 0.786 & 0.777 \\
\hline
\end{tabular}

\section{Validity}

The CVI score (0.88) indicated that the BSCP had good content validity. The KMO index and Bartelett's test results shows that the sampling adequacy was accepted as suitable for factor analysis. According to the results of the total variance explanation and scree plot, the Turkish version of the BSCP has six factors too and the present results of this study were supported by the original BSCP [25]. The six subscales explained $67.8 \%$ of variance. The Exploratory factory analysis (EFA) found that the item factor loadings ranged from .54 to .86 . However, the item factor loading in the original development of the BSCP was between .49 and .84 [25]. After the EFA evaluation in the present study, Confirmatory Factory Analysis (CFA) was conducted for assessing the scale. The CFA indicated that the Turkish BSCP had a good fit index [32].

\section{Reliability}

The reliability analysis in this study indicated an acceptable internal reliability of the BSCP scale, as Cronbach Alpha scores of all six subscales were over 0.66 . The internal consistency of the original study, the Cronbach Alpha scores for each sub-scale was as follows: Active solution $=0.71$, Seeking help for solution $=0.69$, Changing

\section{Discussion}

The present study investigated the validity and reliability of the Turkish version of the BSCP for assessing stress coping profiles in textile workers. The BSCP, originally developed for Japanese workers, is documented to assess coping profiles and consists of 6 different subscales covering a broad domain of coping strategies of workers' job stress experiences. The six subscales can be used separately. It does not have a total score [25]. It is short and easy to implement at work (Table 4). mood=0.77, Changing a point of view=0.71, Emotional expression involving others $=0.64$ and Avoidance and suppression=0.72. The Cronbach Alpha score indicated that the reliability of the Turkish version of the BSCP had an acceptable index [33]. Compared to findings in the original Japanese version of the BSCP, four subscales showed better reliability in the present study. Tomutsune et al. [4] used the BSCP scale for assessing employees in educational and scientific institutions in Japan. Active solution ( $r=0.86)$, Seeking help for solution $(r=0.80)$ and Changing mood $(r=0.78)$ subscales had higher Cronbach Alpha's scores when compared to the present and the original BSCP studies [4]. However, "Changing a point of view", "emotional expression involving others" and "avoidance and suppression" subscales internal consistency in the present study was better than both studies above in Japan.

\section{Conclusion and Recommendations}

The current study translated and assessed an internationally recognized brief measurement tool for stress coping profiles of workers, the BSCP, into Turkish. The results showed that the scale has acceptable validity and reliability. The Turkish version of the BSCP is the first adapted scale in Turkey for evaluating workers' coping strategies. More than one third of Turkey's population 
is actively engaged with work. Thus, the measurement can be a good option to be used for assessing coping profiles with job stressors by occupational health nurses, physicians, psychologist and safety experts in Turkey. It is short and easy to conduct at the workplace. The scale will be a good option to provide basic data about workers' coping profiles which may be used for prolonging stress management skills and health promotion programs. The sample of the study does not represent all the workers in Turkey. Therefore, the results should not be generalized to all workers in Turkey. In addition, further testing of the Turkish version of the BSCP with different sector's workers and socioeconomic class is recommended.

\section{References}

1. Turk Stat (2017) Labour force istatistics (no: 24941).

2. ILO (2014) Wages and working hours in the textiles, clothing, leather and footwear industries. International Labour Organization, Geneva, Swtizerland.

3. Health and Executive (2016) Work related stress, anxiety and depression statistics in the Great Britain

4. Tomotsune Y, Sasahara S, Umeda T, Hayashi M, Usami K, et al. (2009) The association of sense of coherence and coping profile with stress among research park city workers in Japan. Ind Health 47(6): 664-672.

5. Nakagawa Y, Inoue A, Kawakami N, Tsuno K, Tomioka K, et al. (2014) Effect modification by coping strategies on the association of organizational justice with psychological distress in Japanese workers. J Occup Health 56(2): 111-123.

6. Takeda K, Watanabe Y (2017) Recognition of factors related to low back pain promotes behavior change among female nurses. Journal of USChina Medical Science 14: 8-18.

7. Cortina LM, Wasti SA (2005) Profiles in coping: responses to sexual harassment across persons, organizations, and cultures. J Appl Psychol 90(1): 182-192.

8. Inoue A, Kawakami N, Eguchi H, Tsutsumi A (2016) Buffering effect of workplace social capital on the association of job insecurity with psychological distress in Japanese employees: a cross-sectional study. J Occup Health 58(5): 460-469.

9. Doron J, Trouillet R, Maneveau A, Neveu D, Ninot G, et al. (2015) Coping profiles, perceived stress and health-related behaviors: a cluster analysis approach. Health Promot Int 30(1): 88-100.

10. Suzuki A, Sakurazawa H, Fujita T, Akamatsu R (2016) Overeating, late dinner, and perceived stress in Japanese workers. Obes Res Clin Pract 10(4): 390-398.

11. Sugawara N, Sato K, Takahashi I, Satake R, Fukuda S, et al. (2017) Depressive symptoms and coping behaviors among individuals with irritable bowel syndrome in Japan. Intern Med 56(5): 493-498.

12. Cheng C, Lau HP, Chan MP (2014) Coping flexibility and psychological adjustment to stressful life changes: A meta-analytic review. Psychol Bull 140(6): 1582-1607.

13. Butler JM, Hirshberg EL, Hopkins RO, Wilson EL, Orme JF, et al. (2016) Preliminary identification of coping profiles relevant to surrogate decision making in the ICU. PloS One 11(11): e0166542.

14. Gambetta TK, Marino R, Morgan M, Anderson V (2016) Coping strategies and the Salutogenic Model in future oral health professionals. BMC Medical Education 16(1): 224.

15. Tabała K, Wrzesińska M, Stecz P, Kocur J (2016) Personality traits, level of anxiety and styles of coping with stress in people with asthm and chronic obstructive pulmonary disease-a comparative analysis. Psychiatr Pol 50(6): 1167-1180.

16. Duygun T, Nilhan S (2013) Zihinsel engelli ve sağlikli çocuk annelerinde stres belirtileri, stresle başaçikma tarzlari ve algilanan sosyal desteğin tükenmișlik düzeyine olan etkisi. Türk Psikoloji Dergisi 18(52): 37-52.

17. Ekinci M, Altun ÖŞ, Can G (2013) Hemşirelik öğrencilerinin stresle başa çikma tarzlari ve atilganlik düzeylerinin bazi değișkenler açisindan incelenmesi (examination of the coping style with stress and the assertiveness of the nursing students in terms of some variables). Psikiyatri Hemşireliği Dergisi 4(2): 67-74.

18. Engin DM, Yılmaz E (2016) Üniversite öğrencilerinde duygusal zeka ve stresle bașa çkma stilleri arasındaki ilișkinin incelenmesi (An Investigation of the relationship between emotional and coping with stress styles of the University students). Türk Psikolojik Danıșma ve Rehberlik Dergisi 3(25): 17-26.

19. Sahin NH, Durak A (1995) Stresle bașa çıkma tarzları ölçeği: Üniversite öğrencileri için uyarlanması. Türk Psikoloji Dergisi 10(34): 56-73.

20. Selçuk EB, Șelçuk ȘZ, Tetik B, Kayhan D, Özcan ÖÖ, et al. (2016) Zihinsel engelli çocuğu olan annelerin anksiyete ve stresle başa çikma becerileri ve ilişkili değişkenlerin belirlenmesi (evaluating anxiety and stress coping skills and related variables of mothers with mentally retarded children). Journal of Turgut Ozal Medical Center 23(1): 1-5.

21. Tumkaya S (2016) Öğretmenlerin tükenmișlik düzeyleri ve kullandıkları başa çıkma davranışları (Burnout Levels and Coping Behaviours of Teachers). Türk Psikolojik Danıșma ve Rehberlik Dergisi 2(11): 26-36.

22. Yllmaz SD, Beji NK (2010) Gebelerin stresle başa çıkma, depresyon ve prenatal bağlanma düzeyleri ve bunları etkileyen faktörler (Levels of coping with stres, depression and prenatal attachment and affecting factors of pregnant women). Genel Tip Derg 20(3): 99-108.

23. Kaneko S, Momino K (2015) Stress factors and coping behaviors in nursing students during fundamental clinical training in Japan. International Journal of Nursing \& Clinical Practices 2(2): 138-144.

24. Yamagishi M, Kobayashi T, Kobayashi T, Nagami M, Shimazu A, et al (2007) Effect of web-based assertion training for stress management of Japanese nurses. J Nurs Manag 15(6): 603-607.

25. Kageyama T, Kobayashi T, Kawashima M, Kanamaru Y (2004) Development of the Brief Scales for Coping Profile (BSCP) for workers: basic information about its reliability and validity. Sangyo Eiseigaku Zasshi 46(4): 103-114.

26. Waltz CF, Bausell BR (1983) Nursing research: Design, statistics and computer analysis ( $2^{\text {nd }}$ edn), FA Davis, Philadelphia, USA

27. Polit DF, Beck CT (2006) The content validity index: Are you sure you know what's being reported? Critique and recommendations. Res Nurs Health 29(5): 489-497.

28. Kaiser HF (1974) An index of factorial simplicity. Psychometrika 39(1): 31-36.

29. Cattell RB (1966) The scree test for the number of factors. Mulitivariate Behav Res 1(2): 245-276.

30. Tabachnick BG, Fidell LS (2007) Using Multivariate Statistics ( $5^{\text {th }}$ edn), Allyn and Bacon, Boston, USA

31. Kline RB (2005) Principles and Practice of Structural Equation $\left(2^{\text {nd }}\right.$ edn $)$, Guilford, New York, USA.

32. Harrington D (2009) Confirmatory factor analysis. Oxford University press, New York, USA

33. Tavakol M, Dennick R (2011) Making sense of Cronbach's alpha. Int J Med Educ 2: 53-55. 